\title{
緜滴法による $\mathrm{CaO}-\mathrm{SiO}_{2}, \mathrm{CaO}-\mathrm{Al}_{2} \mathrm{O}_{3}, \mathrm{CaO}-\mathrm{Al}_{2} \mathrm{O}_{3}-\mathrm{SiO}_{2}$ 系 溶融スラグの表面張力の測定*
}

\author{
向井楠 宏** 石川友 美*** \\ J.Japan Inst. Metals.Vol.45. No.2(1981).pp.147 154 \\ Surface Tension Measurements on Liquid Slags in $\mathrm{CaO}-\mathrm{SiO}_{2}, \mathrm{CaO}-\mathrm{Al}_{2} \mathrm{O}_{3}$ and \\ $\mathrm{CaO}-\mathrm{Al}_{2} \mathrm{O}_{3}-\mathrm{SiO}_{2}$ Systems by a Pendant Drop Method
}

Kusuhiro Mukai** and Tomomi Ishikawa***

The pendant drop method has been developed to measure the surface tension of liquid slag in the static and dynamic conditions by controlling the size of the pendant drop with the aid of Pt-Rh $(20 \%)$ coil in contact with the slag. Surface tension in dynamic condition, that is, during the rapid change of the drop size, shows a tendency to differ from that in the static condition. Surface tension in the static condition and the temperature coefficient of the surface tension were determined for the liquid $\mathrm{CaO}-\mathrm{SiO}_{2}, \mathrm{CaO}-\mathrm{Al}_{2} \mathrm{O}_{3}$, and $\mathrm{CaO}-\mathrm{Al}_{2} \mathrm{O}_{3}-$ $\mathrm{SiO}_{2}$ slags in the temperature range from the vicinity of liquidus temperature to $1873 \mathrm{~K}$. $\mathrm{SiO}_{2}$ lowers the surface tension while it raises the temperature coefficient of the surface tension from negative at lower $\mathrm{SiO}_{2}$ contents to positive at higher $\mathrm{SiO}_{2}$ contents of $\mathrm{CaO}-\mathrm{SiO}_{2}$ and $\mathrm{CaO}-\mathrm{Al}_{2} \mathrm{O}_{3}-\mathrm{SiO}_{2}$ slags. At constant $\mathrm{SiO}_{2}$ contents of $\mathrm{CaO}-\mathrm{Al}_{2} \mathrm{O}_{3}-\mathrm{SiO}_{2}$ slag, $\mathrm{Al}_{2} \mathrm{O}_{3}$ lowers the surface tension except for a narrow range of high $\mathrm{SiO}_{2}$ contents and low $\mathrm{Al}_{2} \mathrm{O}_{3}$ contents, while it raises the temperature coefficient of surface tension except for the range of high $\mathrm{SiO}_{2}$ content. The surface tension $\mathrm{vs}^{\mathrm{SiO}_{2}}$ content curve shows a tendency to have a hump in the vicinity of wollastonite and gehlenite for the $\mathrm{CaO}-\mathrm{SiO}_{2}$ and $\mathrm{CaO}-\mathrm{Al}_{2} \mathrm{O}_{3}-\mathrm{SiO}_{2}$ slags respectively.

(Received July 17, 1980)

\section{I. 緒 言}

高温度での溶融スラグの表面張力は大部分が最大泡圧法 により,ごく一部が静滴法,浸漬円筒法により測定されてい る(1). しかし比較的測定值が多い $\mathrm{CaO}-\mathrm{SiO}_{2}$ 系でも，最大 泡圧法と浸清円筒法とでは測定值に大きな相違がある(2). また同じ最大泡圧法による最近の測定結果でも十分な一致 は得られていない(2)。それぞれの測定法には一長一短があ り，㵋定値の信頼性を調べるには，同一測定系に対して従 来の測定法とは異なる方法での測定が望をれる。著者らの 一人 ${ }^{(3)}$ は以前, 懸滴法を溶融スラグの表面張力の測定に適 用することを試みたが，本研究はをれと同様の装置を用い て, $\mathrm{CaO}-\mathrm{SiO}_{2}, \mathrm{CaO}-\mathrm{Al}_{2} \mathrm{O}_{3}, \mathrm{CaO}-\mathrm{Al}_{2} \mathrm{O}_{3}-\mathrm{SiO}_{2}$ 系溶融ス グの表面張力の湘定を行なったものである、愻滴法は, 被




自由に变えられるので，㲘滴の变形流動の際の粘性の寄与 などを分離することができれば，大きさが変化している状
態での表面張力の測定ができ,スラグの泡立ちに関保が樑 いとされている表面面積粘性の測定が可能になるすのと思 われる。

\section{II. 実 験 方 法}

Fig.1 亿示す懸滴の形状より，式(1)を用いてスラグの 表面張力

$$
\gamma=\rho_{g} d_{\varepsilon}^{2} F
$$

$\rho$ はスラグの密度, $g$ は重力加速度, $F$ は $d_{e} / d_{s}$ の関数で Fordham ${ }^{(4)}$ の表から求めた。

\section{1. 実駼装置}

測定用加熱炉，写真撮影装置，ガス精製装置などはす べて前報 ${ }^{(3)}$ と同一であるので省略する。Fig.1亿湘定部の 概要を示す。スラグ滴はロート状 $\mathrm{Pt} \cdot \mathrm{Rh}(20 \%)$ 製容器の 下部の紐管 (内径 $2.9 \sim 3.9 \mathrm{~mm}$, 厚さ $0.3 \mathrm{~mm}$ ) の先端か ら垂れ下がり，Pt.Rh 製容器のスラグ上面に接触させた 扁平渦巻状のPt.Rh コイルを押下げれば,スラグが押下

\footnotetext{
*** 九州工業大学金属加工学科(Department of Metallurgy, Kyushu Institute of Technology, Kitakyushu)

*** 九州工業大学大学院, 現在 : 本田技術研究所朝霞研究所 (Graduate Schoo1, Kyushu Institute of Technology, Kitakyushu.Present address : Honda $\mathrm{R}$ and D Co. Ltd., Asaka)

* 1977 年 10 月日本金属学会広島大会に発表
} 


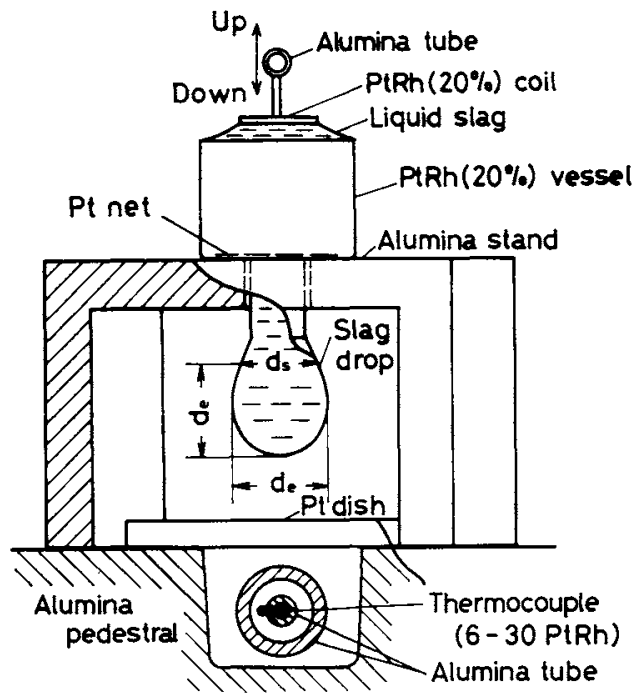

Fig.1 Schematic drawing of the arrangement for the measurement of surface tension of liquid slag by the pendant drop method.

げられてスラグ滴は大きくなり，引上げれば小さくなる。 また，スラグ滴の適当な大きさでコイルを静止させれば， スラグ滴はほ注一定の大きさを保つ。

\section{2. 湨定操作}

Pt.Rh 容器の上部太管 (内径 9.6 14.6 mm) の底，すな わち下部細管への入口に $0.3 \mathrm{~mm}$ 線径のPt 網を數き，そ の上にスラグ約 $2 \sim 5 \mathrm{~g}$ を入れ，容器の細管部が炉内で垂 值になるようにセットした. Pt.Rh 容器直上のPt.Rh コ イルは，容器上部のスラグ表面に正確に降下するように詷 節した．Pt絧はスラグを容器の細管部から押出して谪を 大きくする際に，スラグの急激な流動を挡え，滴の落下を 防止するために用いた．精製 Ar 気流中で昇温し，スラグ の溶融後 Pt.Rh コイルを Fig.1 に示すよらにスラグ表面 に接触させ，コイルを上下して䈍滴の大きさを誠節した。

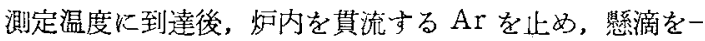
定の大きさに保持し，900 $\mathrm{s}$ 間にわたって滴の写真撮影を 行なった. 撮影したホガフィルム上の彩滴の像より， $d_{e}$ ， $d_{s}$ を工場顕徽鏡 $(1 / 1000 \mathrm{~mm}$ 昰で読取可能)を用いて測定 した.

スラグ試料： $\mathrm{CaO}$ は試薬特級の $\mathrm{CaCO}_{3}$ を加熱分解し， $\mathrm{Al}_{2} \mathrm{O}_{3}$ は市販アルミナ粉 $\left(99.7 \% \mathrm{Al}_{2} \mathrm{O}_{3}\right)$ を乾燥し, $\mathrm{SiO}_{2}$ は 透明石英 $\left(99.99 \% \mathrm{SiO}_{2}\right)$ を粉哗，洗浄，乾燥したものを用 いた．上記 $\mathrm{CaO}, \mathrm{Al}_{2} \mathrm{O}_{3}, \mathrm{SiO}_{2}$ 粉を目標組成に調合し，打 柱状以焼き固めたものをプラズマジェットボタン溶解炉で 約 $0.7 \mathrm{~g}$ のボタン状に溶製し，測定に供した，スラグ組成 は湘定前のスラグの化学分析から求めた。

\section{III. 実験結果と考察}

\section{1. 測定上の問題点の検討}

写真撮影：本装置で初期に撮影した䀣㘖の下端には，ぼ
けが生じ，これが $d_{s}$ の測定の大きな鿁差の原丙となった。 そこで䯚滴の後方約 $15 \mathrm{~cm}$ の位置にアルミナの衝立を置 いたところ，鮮明な愳滴像が得られた。このぼけの原因は

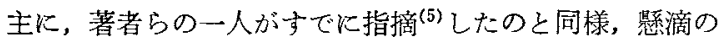
下端が背景となる炉心管の出口の暗黑部を映しているため であると考文られる。露出時間は1/500sで, Photo.1に 撮影した懸滴の一例を示す。

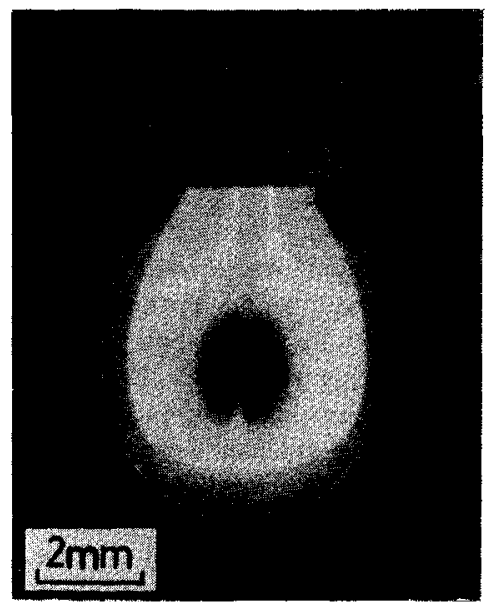

Photo.1 Shape of the pendant drop of slag No.3 at $1873 \mathrm{~K}$.

このよらにして得た同一フィルムの像を同一測定者が繰 返し 5 回測定した結果, 表面張力のばらつきは土1 $\mathrm{mN} / \mathrm{m}$ 以内にあった。

倍率：式 $(1) の d_{e}$ をィルムの像から求めるに必要な


(JIS 挸格上級)の像から求めた，攝影见祭しては，豆電球 を、鋼球とカメラの間に，フルミナ炉心管の内壁に沼って 同心円状に並べることによって，カメラ方向から光をあて 実際の湘定の場合之同じ状態で撮影し，現像時のかぶりの 影響をなくした。さらに，倸滴と同程度の大きさの鋼球を

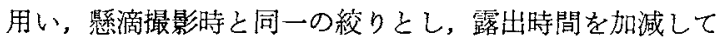
鯀滴撮影時と同程度の濃さに写し出すことによって倍率測 定の楞差を小さくした。

密度：最大泡压法などと異なり，慜滴法では式(1)のス ラグの密度は，独立に求めなけ机ならない，本研究では $\mathrm{CaO}, \mathrm{Al}_{2} \mathrm{O}_{3}, \mathrm{SiO}_{2}$ 成分の理想湿合を仮定し，次式より密 度を求めた。

$$
\rho=\sum M_{i} x_{i} / \sum V_{i} x_{i}
$$

$M_{i}, x_{i}, V_{i}$ ，はそれぞれ成分 $i$ 分子量，モル分率，モル 体積である、CaO- $\mathrm{SiO}_{2} 2$ 成分系では, Lee ら (6)の密度の 夹測僆とBockris $5^{(7)}$ の $\mathrm{SiO}_{2}$ のモル体積 $V^{\circ} \mathrm{SiO}_{2}=27.0$ $\times 10^{-6} \mathrm{~m}^{3} / \mathrm{mol}$ を用いて $V_{\mathrm{C} 乞 \mathrm{O}}$ を算出した。 Lee $b^{(6)}$ の密 度の実測組成で算出した $V \mathrm{c}_{\mathrm{n}} \mathrm{O}$ のなかで，表面張力の測定 組成炕最子近い $V \mathrm{CaO}$ を用いて式 $(2)$ 上り表面張力の㵋 定組成での密度 $\rho$ を算出した。 $\mathrm{CaO}-\mathrm{Al}_{2} \mathrm{O}_{3}-\mathrm{SiO}_{2}$ 系では Kammel $5^{(8)}$ の密度の実測値を，京た $\mathrm{CaO}-\mathrm{Al}_{2} \mathrm{O}_{3}$ 系では 
向井ら ${ }^{(9)}$ の実測値を用い，上記 $\mathrm{CaO}-\mathrm{SiO}_{2}$ 系での $V^{\circ} \mathrm{SiO}_{2}$, $V \mathrm{CaO}$ をとに $V_{\mathrm{Al}_{2} \mathrm{O}_{3}}$ を求め, $\mathrm{CaO}-\mathrm{SiO}_{2}$ 系と同様にし て表面張力の測定緼成での $\rho$ を算出した。このようにし て得られる密度は，密度の実測組成の互いに隣りあら組成 での $V_{i}$ を用いて算出しても実測值とよく一致し，両者の 差は表面張力にして $1.5 \mathrm{mN} / \mathrm{m}$ 以内と見積ることがで きた。 ま mol\% 付近は Kammel $b^{(8)}$ と向井 ${ }^{(9)}$ の測定値の空白領 域であるが，両者の実測值をもとに式(2)からそれぞれに 算出した上記組成での密度の差は, 表面張力にして $5 \mathrm{mN} /$ $\mathrm{m}$ 程度であった。

懸滴の大きさの変化: Fig.2に, Pt.Rh コイルを動か さずに $900 \mathrm{~s}$ 間整滴を保持した後、コイルを上げて滴を小 さくし，次にコイルを下げて滴を押出し大きくしたときの

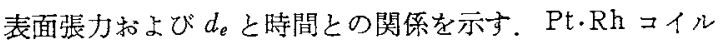
の伸びなどによって自然に变化する程度の縣滴の大きさの 経時変化(900s まで)は表面張力の湘定值に影響せず，450 $\sim 900 \mathrm{~s}$ では表面張加 $\pm 1.5 \mathrm{mN} / \mathrm{m}$ 以内のばらつきで, 一定值を示す。しか乙滴を急激に小さくしていくと，表面 張力は低下し，次に急激に大きくしていくと表面張力はも との值に回復する頵向を示す。このような表面張力の低 下，回復現象は，滴の縮小，増大に伴ら滴表面の表面活性 成分の濃化，希釈によって生じると考えることができる。 しかし滴の縮小增大洔に粘㤬流動などの影響が無視しえな い場合には，䀣滴法の湘定原理である静的な力学的平衡が 満たされていないので，式(1)ょり算出されるとの値は単 なるみかけ上の表面張力の值にすぎなくなる，組成は異な るが粘性が同程度の系を使用するなどして，粘性流動など の動的要因の影響を分離することができれば，本測定法に よって滴の縮小增大時の表面張力の測定から，スラグの泡 立ちに重要な役割を果すと考允られている表面面積粘性の 湘定が可能になる筈である。

表面張力の経時変化：䄸滴形成後，コイルを動かさずに 沾を維持した場合，表面張力はFig.2 に示すよ5に $450 \mathrm{~s}$

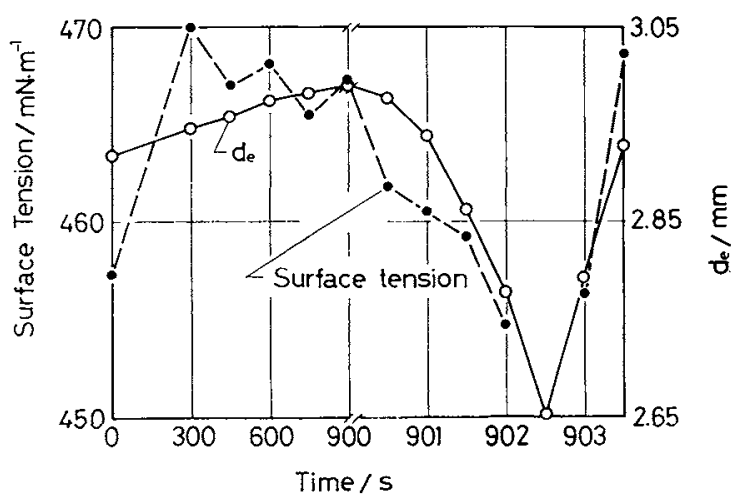

Fig.2 Relation between surface tension of slag No.23 and time variation of the size of the pendant drop at $1873 \mathrm{~K}$.
以後、フィルム測定のばらつきの範田程度で一定の值に落 着くので 600 900 s の間の值を测定值として採用した.

Table 1 飞は，1回の実駼で得られた各温度に出壮る表 面張力の平均値とその際に用いた式(2)より算出の密度の 値を示す.

測定值の再現性：スラグ No.5 で纯 3 回の実験を行ない 湘定佰の再現性を調べた，その結果 $\pm 2 \mathrm{mN} / \mathrm{m}$ のばらつ きを示した， $\mathrm{O}_{2}$ 雾㬰気でも同様の央験を行なった結果,

Fig.3に示すよらに $1.5 \mathrm{mN} / \mathrm{m}$ のばらつきを示した. $\mathrm{Pt} \cdot \mathrm{Rh}$ 細管が垂直力们からずれて傾くと滴の対称性が悪 くなり，表面張力のばらつきは $\pm 6 \mathrm{mN} / \mathrm{m}$ 程度に增大し た。したがって，Pt・Rh 細管の傾いた対称性の悪い滴の 䁚定值は除外した。しかし，滴の対称性の良否の判別は炉 の半径方向のみで可能であり，軸方向すなわち前後方向の 判別は撮影フィルムからはできないここのことを考慮すれ ば，士6 $\mathrm{mN} / \mathrm{m}$ 程度のばらつきは要りらるものと考えな けれぱならない。

\section{2. $\mathrm{CaO}_{-} \mathrm{SiO}_{2}$ 系}

表面張力之組成との関係: $\mathrm{CaO}-\mathrm{SiO}_{2}$ 系の表面張力につ いては，現在までたかなりの数の测定結果が報告(2)(20)〜(19) されている，Fig.3には，そのなかで組成範囲が広く，測定 点の多いるのを選んで本湘定結果ととるに示した。本測定 結果は最近の浿定結果(Ar中)である Sharma $5^{(18)}$ と 郡司ら (2)の僆の中間にある、三者の值は,Fig.3に示す湘定 者間の相違に比較すれば，かなりよく一致し始めたといえ るが，な就 30〜40 $\mathrm{mN} / \mathrm{m}$ の相違がある。この相違の原因 については，測定法に起因するもの即ら，懸滴法では密度 の同時測定ができず，他の方法で求めた值を用いているこ と，最大泡生法にも毛管径の見積り，異常現象 ${ }^{(2)}$ な゙末解 決の問題のあることが指摘でさる。さらに，同じ最大泡压 法, Ar 雲囲気でもSharma ら ${ }^{(18)}$ と郡司ら (2) の間には 30 $\sim 40 \mathrm{mN} / \mathrm{m}$ の相違がある，両者は毛管がそれぞれ Mo と $\mathrm{Pt} \cdot \mathrm{Rh}$ と異なるが，これが相違の原因の一つになってい るのかもしれない。

本測定結果は従来の测定結果と同様, $\mathrm{SiO}_{2}$ 濃度の增加 とともに表面張力が全体として低下する傾向を示す。しか L $r-\% \mathrm{SiO}_{2}$ 曲線に Wollastonite $\left(\mathrm{CaO} \cdot \mathrm{SiO}_{2}\right)$ 組成付近で 凸部が現われる、 $\gamma-\% \mathrm{SiO}_{2}$ 曲線を滑らかな単調娍少曲線 で描いた場合，この曲線からの眼定值の偏倚はばらつき $\pm 6 \mathrm{mN} / \mathrm{m}$ より大きくなり，山部を貺定值のばらつきとみ なすのはむすかいい、このよう沈 $\mathrm{SiO}_{2}$ が Wollastonite 組成付近の 50〜60 mol\% で異常な挙動を示す他の例とし ては，粘性の活性化エネルギー ${ }^{(20)}$ とその頻度因子 ${ }^{(20)}$ ，導 電率の活珄化土ネルギー(21) とその頻度因子(21) があり， 密度にも Tomlinson ら ${ }^{(22)} の$ 結果のように異常な傾向の 認められるものか゚ある. Tomlinson ら ${ }^{(22)}$ の密度を本測定 の $\gamma$ 算出に用いれば， $\gamma-\% \mathrm{SiO}_{2}$ 曲線の凸部はもっと顕 著になる。 
Table 1 Results of surface tension measurements. Values of density were calculated from eq. (2) by using data of other investigators.

\begin{tabular}{|c|c|c|c|c|c|c|c|c|c|c|c|c|c|c|c|}
\hline & S1 & $\mathrm{ag}$ & & & & & & & Sl & ag & & & & & \\
\hline No. & Comp & osition & $1 \%$ & & & & & No. & Comp & osition & $\mathrm{mol} \%)$ & & & & \\
\hline & $\mathrm{CaO}$ & $\mathrm{Al}_{2} \mathrm{O}_{3}$ & $\mathrm{SiO}_{2}$ & $\begin{array}{l}17 \overline{23} \\
(\mathrm{~K})\end{array}$ & $\begin{array}{c}1773 \\
(\mathrm{~K})\end{array}$ & $\begin{array}{l}1823 \\
(\mathrm{~K})\end{array}$ & $\begin{array}{l}1873 \\
(\mathrm{~K})\end{array}$ & & $\mathrm{CaO}$ & $\mathrm{Al}_{2} \mathrm{O}_{3}$ & $\mathrm{SiO}_{2}$ & $\left|\begin{array}{c}1723 \\
(\mathrm{~K})\end{array}\right|$ & $\begin{array}{l}1773 \\
(\mathrm{~K})\end{array}$ & $\begin{array}{l}1823 \\
(\mathrm{~K})\end{array}$ & $\begin{array}{l}1873 \\
(\mathrm{~K})\end{array}$ \\
\hline 1 & 365 & - & 635 & 一 & 403.1 & 404.1 & 407.8 & 18 & 30 4 & 163 & 533 & - & 411.7 & 411.8 & 416.9 \\
\hline & & - & 00.0 & 一 & 2.524 & 2.509 & 2.495 & & & & & - & 2.480 & 2.476 & 2.474 \\
\hline 2 & 416 & - & 58.4 & 一 & 413.2 & 413.2 & 412.9 & 19 & 35.9 & 129 & 512 & 430.3 & 431.7 & 434.7 & 432.5 \\
\hline & 41.0 & 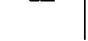 & 50.4 & - & 2.574 & 2.556 & 2.539 & & & & 51.2 & 2.520 & 2.514 & 2.508 & 2.502 \\
\hline 3 & 12 2 & & & - & 430.1 & 433.7 & $|431.5|$ & ת0 & 147 & 13 & & - & 442.5 & 443.7 & 448.8 \\
\hline 3 & 42.3 & - & 57.7 & - & $\overline{2.580}$ & 2.562 & 2.545 & 20 & 44.8 & 4.3 & 51.0 & - & 2.552 & $\overline{2.543}$ & $\overline{2.536}$ \\
\hline 4 & 437 & - & 563 & - & 436.3 & 435.8 & 436.8 & 27 & 441 & 88 & 168 & 458.1 & 458.5 & 459.5 & 457.6 \\
\hline 4 & 43.7 & - & 56.3 & - & $\overline{2.571}$ & $\overline{2.557}$ & $\overline{2.544}$ & 21 & 44.4 & 8.8 & 40.8 & 2.576 & $\overline{2.567}$ & $\overline{2.561}$ & 2.554 \\
\hline $5-1$ & $16 ?$ &  & 538 & - & - & 451.3 & 448.4 & ?? & 270 & 270 & 110 & - & - & 434.5 & 436.1 \\
\hline $5-1$ & 40.2 & - & 53.0 & - & - & 2.560 & 2.550 & 22 & 21.0 & 20.0 & 40.0 & - & - & $\overline{2.475}$ & 2.473 \\
\hline $5-2$ & $14 ?$ & 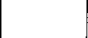 & 528 & - & $* * 444.4$ & $* 443.5$ & 445.5 & 23 & $20 ?$ & 151 & 457 & 462.0 & 460.9 & 466.6 & 467.3 \\
\hline $5-2$ & 40.2 & - & 53.8 & - & $\overline{* * 2.565}$ & $\overline{* 2.558}$ & 2.550 & 25 & 39.2 & 10.1 & 40.6 & 2.549 & 2.544 & 2.538 & 2.534 \\
\hline $5-3$ & $16 ?$ & 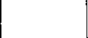 & 538 & - & $* * 443.7$ & $* 441.8$ & $444.5 \mid$ & 21 & 598 & 1 & 151 & - & 480.7 & 480.9 & 480.7 \\
\hline 5 & 40.2 & & 20.0 & - & $* * 2.565$ & $* 2.558$ & $\overline{2.550}$ & 24 & 01.0 & 0.1 & 45.1 & - & 2.624 & 2.617 & 2.610 \\
\hline $6-1$ & 193 & $\ldots$ & 507 & - & - & $* 449.3$ & 450.9 & 25 & 207 & 15. & 1418 & 470.9 & 473.5 & 474.3 & 473.9 \\
\hline $0-1$ & 49.3 & - & 50.8 & - & - & $* 2.585$ & 2.576 & 20 & 39.8 & 10.5 & 44.8 & 2.555 & $\overline{2.549}$ & $\overline{2.543}$ & $\overline{2.539}$ \\
\hline $6-2$ & 193 &  & 507 & - & - & $* 454.6$ & $|455.1|$ & 2 & 256 & 0 & 148 & 450.6 & 452.8 & 452.8 & 455.3 \\
\hline $0-2$ & 49.0 & - & 30.8 & - & - & $* 2.585$ & 2.576 & 20 & 35.0 & 20.0 & 44.4 & 2.523 & 2.518 & $\overline{2.514}$ & $\overline{2.509}$ \\
\hline 7 & 525 & 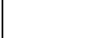 & 175 & - & $1+462.8$ & +460.5 & 461.9 & 27 & 160 & 0 & 127 & 486.5 & 484.1 & 484.9 & 487.8 \\
\hline$r$ & 32.0 & & 47.5 & - & $\uparrow 2.618$ & $\overline{\dagger 2.612}$ & 2.605 & $2 t$ & 40.3 & 0.0 & 40.1 & 2.583 & 2.577 & 2.571 & 2.564 \\
\hline 8 & $55^{\prime}$ & - & $40^{0}$ & - & 491.8 & 490.3 & $\mid 491.8$ & 28 & 300 & 0. & 11 & - & $\ldots$ & 459.6 & 460.3 \\
\hline 0 & 00.1 & & 44.9 & - & 2.641 & 2.627 & 2.613 & 20 & 30.0 & 20.0 & 41.0 & - & - & 2.504 & 2.504 \\
\hline 10 & 170 & $11 ?$ & & 387.9 & 391.9 & 394.4 & 398.6 & ת0 & 120 & 0 & 20 & 490.6 & 487.7 & 488.9 & 487.1 \\
\hline 10 & 17.0 & 11.3 & 71.8 & 2.355 & 2.356 & 2.357 & 2.359 & 29 & 40.0 & 10.9 & 39.0 & 2.584 & 2.577 & 2.571 & 2.565 \\
\hline 11 & 200 & $\circ$ & t & 392.5 & 398.2 & 400.9 & 404.4 & 30 & 415 & 200 & 27 & 470.7 & 474.7 & 471.9 & 469.6 \\
\hline 11 & 22.0 & 0.0 & 09.4 & $2 . \overline{401}$ & 2.399 & 2.396 & $\overline{2.394}$ & Ju & 41.0 & 20.5 & 58.0 & 2.542 & 2.539 & 2.537 & 2.536 \\
\hline 12 & 208 & 153 & 639 & - & 400.3 & 403.1 & 405.2 & 31 & 464 & 265 & 27 & - & - & - & 522.5 \\
\hline 12 & 20.0 & 10.5 & 00.7 & - & 2.379 & 2.387 & $\overline{2.397}$ & & 20.1 & & 21.1 & - & - & - & 2.577 \\
\hline 13 & 296 & 70 & 621 & 402.3 & 407.8 & 410.6 & 411.2 & 32 & 497 & 274 & 229 & - & - & - & 536.2 \\
\hline & 20.0 & 1.0 & 00.4 & 2.448 & 2.447 & 2.445 & 2.444 & & & & 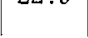 & - & - & - & 2.601 \\
\hline 14 & 229 & 138 & 633 & 400.7 & 398.5 & 400.9 & 403.4 & 33 & 55. & $29=$ & 151 & - & - & 558.7 & 558.2 \\
\hline $1 x$ & & 10.0 & 00.0 & 2.401 & $\overline{2.402}$ & $\overline{2.403}$ & $\overline{2.404}$ & 30 & 50.4 & 25.0 & 10.1 & - & - & $\overline{2.682}$ & 2.666 \\
\hline 15 & $32 ?$ & 178 & 570 & 423.1 & 424.3 & 423.9 & 428.0 & 34 & 588 & 319 & 93 & 590.5 & 590.3 & 587.5 & 585.2 \\
\hline 10 & 20.2 & 10.0 & 36.0 & $\overline{2.482}$ & $\overline{2.478}$ & $2 . \overline{474}$ & $\overline{2.470}$ & 24 & 50.0 & 51.3 & 7.0 & 2.746 & 2.728 & 2.711 & 2.695 \\
\hline 16 & 175 & 271 & 55 & - & - & - & 411.9 & 35 & 625 & 375 & $\overline{-}$ & 635.8 & 635.6 & 631.2 & 626.2 \\
\hline 10 & 17.0 & 27.1 & 50.4 & - & - & & 2.420 & 30 & 02.0 & 3.0 & - & 2.799 & 2.780 & 2.761 & 2.742 \\
\hline 17 & 19.0 & 270 & 54.0 & - & - & - & 415.6 & & & & & & & & \\
\hline & & & & - & - & - & 2.428 & & & & & & & & \\
\hline
\end{tabular}

表面張力そ温度との関係：1回の実騟においてて，湘定は スラグの液相線直上付近から $1873 \mathrm{~K}$ までの間を,平诗 1.5 回の温度サイクルを与兄て行なったが，Fig.4 に示すよう にKing ${ }^{(10)}$ が報告したような表面張力の温度ヒステリシス

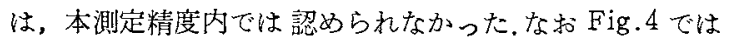

昇温，降温を区別するために，温度の変化方向を矢印で,測

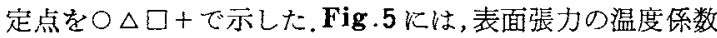
$\mathrm{d} r / \mathrm{d} T$ と $\mathrm{SiO}_{2}$ 濃度との関係を示す。 $\mathrm{d} \gamma / \mathrm{d} T$ は $\gamma$ と $T$ と の関係を直線とみなし， 3 点以上の温度で表面張力の測定 がなされたスラグに最小 2 乗法を適用して求めた。測定点 




Fig.3 Surface tension of $\mathrm{CaO}-\mathrm{SiO}_{2}$ slag.

\begin{tabular}{|c|c|c|c|}
\hline Investigator & $\begin{array}{c}\text { Temp. } \\
(\mathrm{K})\end{array}$ & Atmosphere & Method \\
\hline $\begin{array}{l}\times \text { King }^{(10)} \\
+ \text { Cooper and } \\
\text { Kitchener }\end{array}$ & $\stackrel{1843}{\longrightarrow}$ & $\mathrm{N}_{2}$ & $\begin{array}{l}\mathrm{D}-\mathrm{C} \\
\mathrm{M}\end{array}$ \\
\hline$\square$ Ono et al. (16) & 1873 & $\operatorname{Ar}(\square), O_{2}(\boldsymbol{\square})$ & M \\
\hline $\begin{array}{l}\nabla \text { Sharma and } \\
\text { Philbrook }\end{array}$ & 1873 & Ar & M \\
\hline$\triangle$ Gunji and Dan ${ }^{(2)}$ & 1873 & Ar & $\mathrm{M}$ \\
\hline O $\}$ Present work & 1873 & $\mathrm{Ar}(\mathrm{O}), \mathrm{O}_{2}(\mathbf{0})$ & $P-D$ \\
\hline
\end{tabular}

Method : D-C : Dipping-cylinder method

M: Maximum bubble pressure method P-D : Pendant drop method

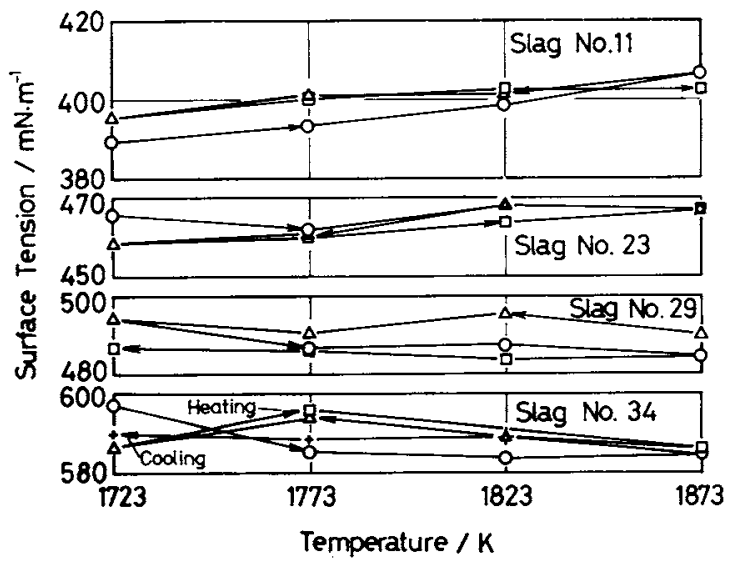

Fig.4 Relation between surface tension and temperature during heating and cooling processes.

の縦線は標準偏差を示すが，図から明らかなよらに $\mathrm{d} r / \mathrm{d} T$ の測定精度は十分なものではない。しかし King(10)の結果 と同様, $\mathrm{SiO}_{2}$ 濃度の增加とともに $\mathrm{d} \gamma / \mathrm{d} T$ は負から正の値

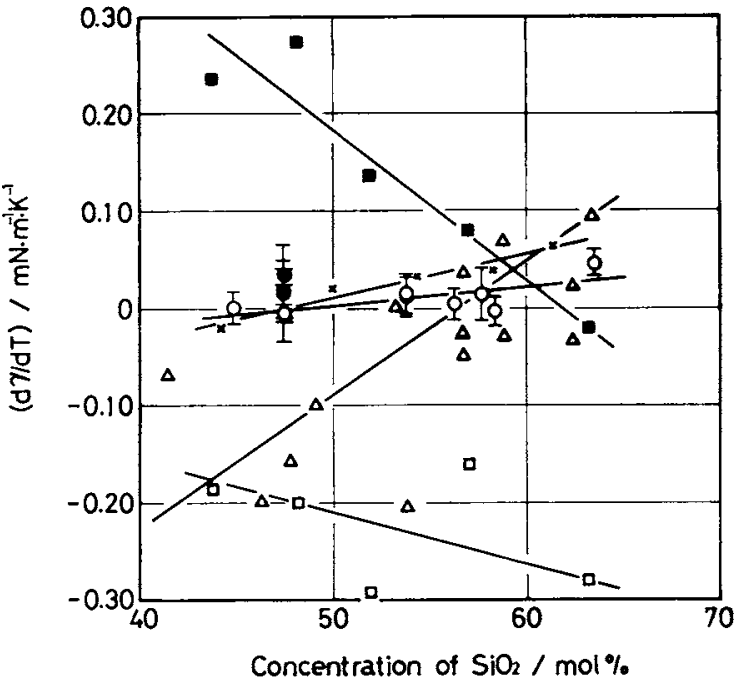

Fig.5 Temperature coefficient of surface tension of $\mathrm{CaO}-\mathrm{SiO}_{2}$ slag.

\begin{tabular}{c|c}
\hline \multicolumn{1}{c|}{ Investigator } & Atmosphere \\
\hline$\times$ King(10) & $\mathrm{N}_{2}$ \\
$\square$ Ono et al. (16) & $\mathrm{Ar}$ \\
$\square$ Ono et al. (16) & $\mathrm{O}_{2}$ \\
$\triangle$ Gunji and Dan ${ }^{(2)}$ & $\mathrm{Ar}$ \\
O Present work & $\mathrm{Ar}$ \\
- Present work & $\mathrm{O}_{2}$ \\
\hline
\end{tabular}

へと增加する傾向を示し，その絶対值は小さい， $\mathrm{Ar}$ と $\mathrm{O}_{2}$ 雲囲気の相違は大きくはないが，O くなる傾问を示し，小野ら ${ }^{(16)}$ の傾问之定性的には一致す る.

\section{3. $\mathrm{CaO}-\mathrm{Al}_{2} \mathrm{O}_{3}$ 系}

$\mathrm{CaO}-\mathrm{Al}_{2} \mathrm{O}_{3}$ 系大ラグの表面張力に関する本測定結果と 他の測定者の值を Fig.6に示す，同じ密度を使用した本 測定值と向井ら(9)の值は互い儿上く一致する。両者はそれ ぞれ懸滴法，静滴法と異なるが，十分に静的な状態で測定 しうる方法であり，両者の一致は両测定法に含まれる密度 以外の系統的誤差が小さいことを示唆する。この系での広

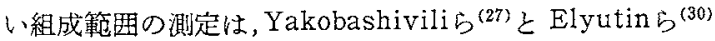
によるものがあるが，測定温度の相違を考虑しても両者の 結果は著しく異なる、本測定值を含めて他のほとんどの測 定値は,Yakobashivili $5^{(27)}$ の結果に近い。ただ，CaO が $70 \mathrm{~mol} \%$ 付近ではこれらの測定者間の相違る大きくなる 傾向がある。

Fig.7 に表面張力の温度係数 $\mathrm{d} \gamma / \mathrm{d} T$ の測定結果を他の 測定者の値とともに示す。本測定值と Evseev ら ${ }^{(29)}$, 向井 $ら^{(9)}$, Elyutin $5^{(30)}$ の值は比較的よく一致する.

4. $\mathrm{CaO}\left(\mathrm{mol}_{\%}\right) / \mathrm{Al}_{2} \mathrm{O}_{3}(\mathrm{~mol} \%)$ 一定における $\mathrm{SiO}_{2}$ 濃度との関保

Fig.8 $6, \mathrm{CaO}(\mathrm{mol} \%) / \mathrm{Al}_{2} \mathrm{O}_{3}(\mathrm{~mol} \%)$ 一定での表面張 力と $\mathrm{SiO}_{2}$ 濃度との関㐿を他の測定結果とともに示す. 図 




Fig.6 Surface tension of $\mathrm{CaO}-\mathrm{Al}_{2} \mathrm{O}_{3}$ slag.

\begin{tabular}{|c|c|c|c|}
\hline Investigator & $|\underset{(\mathrm{T})}{\mathrm{Temp}}|$ & Atmosphere & Method \\
\hline $\begin{array}{l}\text { - Bobkova and } \\
\text { Petukhov (23) }\end{array}$ & 1833 & Ar & $\mathrm{M}$ \\
\hline$\nabla$ Ershov and Popova ${ }^{(24)}$ & 1873 & - & $\mathrm{M}$ \\
\hline$\times$ Deryabin and Popel(25) & 1773 & - & M \\
\hline - Smolyarenko et al. (26) & 1873 & Ar & $\mathrm{M}$ \\
\hline + Yakobashivili et al. ${ }^{(27)}$ & $\begin{array}{r}1753 \sim \\
1853\end{array}$ & $\mathrm{Ar}$ & $\mathrm{M}$ \\
\hline$\square$ Ogino et al. (28) & 1773 & Ar & $\mathrm{M}$ \\
\hline $\begin{array}{l}\Delta \text { Evseev and } \\
\text { Filippov }(29)\end{array}$ & 1873 & $\mathrm{Ar}$ & M \\
\hline - Mukai and Sakao ${ }^{(9)}$ & 1843 & Ar & $\mathrm{S}-\mathrm{D}$ \\
\hline$\triangle$ Elyutin et al. ${ }^{(30)}$ & 2473 & $\mathrm{He}$ & M \\
\hline $\begin{array}{l}\nabla \text { Sikora and } \\
\text { Zielinski(31) }\end{array}$ & 1873 & Ar & $\bar{M}$ \\
\hline$\square$ Zubrev et al. ${ }^{(32)}$ & 1873 & $\mathrm{Ar}$ & $\mathrm{M}$ \\
\hline$\diamond$ Zielinski and Sikora ${ }^{(33)}$ & 1873 & Ar & $\mathrm{M}$ \\
\hline O Present work & 1873 & Ar & $P-D$ \\
\hline
\end{tabular}

Method : S-D : Sessile-drop method

より， $\mathrm{SiO}_{2}$ は 0 72 mol\%に和いて表面活性成分として 作用し，他の測定者の值も $\mathrm{SiO}_{2}$ 濃度䇺团は小さいが，同 様の傾向を示す. Gehlenite $\left(2 \mathrm{CaO} \cdot \mathrm{Al}_{2} \mathrm{O}_{3} \cdot \mathrm{SiO}_{2}\right)$ 組 成付近 では $\mathrm{CaO}-\mathrm{SiO}_{2}$ 系と同様に $\gamma-\mathrm{SiO}_{2}$ 濃度曲線に凹部が現わ れる傾向があり，Ershov ら (24)，Smolyarenko ら (26)の結 果にも同様の傾向を示す可能珄がみてとれる.

Fig.9 には, 表面張力の温度係数 $\mathrm{d} \gamma / \mathrm{d} T$ と $\mathrm{SiO}_{2}$ 濃度 との関係を示す。 $\mathrm{d} r / \mathrm{dT}$ は $\mathrm{SiO}_{2}$ 濃度の増加とともに大き くなり，約 $33 \mathrm{~mol} \%$ で負から正に移行する。 $\mathrm{d} \gamma / \mathrm{d} T$ と $\mathrm{SiO}_{2}$ 濃度との関係を㨁線とみなした場合の勾配は，CaO$\mathrm{SiO}_{2}$ 系の $0.0019 \mathrm{mN} / \mathrm{m} \cdot \% \mathrm{SiO}_{2}$ に対して,本系では0.0017 $\mathrm{mN} / \mathrm{m} \cdot \% \mathrm{SiO}_{2}$ そなり，ほとんど変りはないが， $\mathrm{d} r / \mathrm{d} T$ が 零となる $\mathrm{SiO}_{2}$ 濃度が， $\mathrm{CaO}-\mathrm{SiO}_{2}$ 系より小さい。この傾同 は後述する Fig.11 の等 $\mathrm{d} r / \mathrm{d} T$ 線にも明眿に現われる。本 系に対する他の測定者の值は，Zielinski ら ${ }^{(33)}$ の值しか見

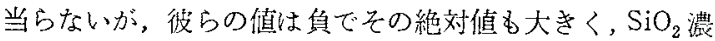
度の増加とともに $\mathrm{d} r / \mathrm{d} T$ は減少する傾向にあり，本澌定 結果と大きく異なる。



Fig.7 Temperature coefficient of surface tension of $\mathrm{CaO}-\mathrm{Al}_{2} \mathrm{O}_{3}$ slag.

$\checkmark$ Ershov and Popova ${ }^{(24)} \nabla$ Sikora and

$\triangle$ Evseev and Filippov ${ }^{(29)} \quad$ Zielinski $^{(31)}$

- Mukai and Sakao(9) $\diamond$ Zielinski and Sikora ${ }^{(33)}$

$\triangle$ Elyutin et al. ${ }^{(30)} \quad$ O Present work

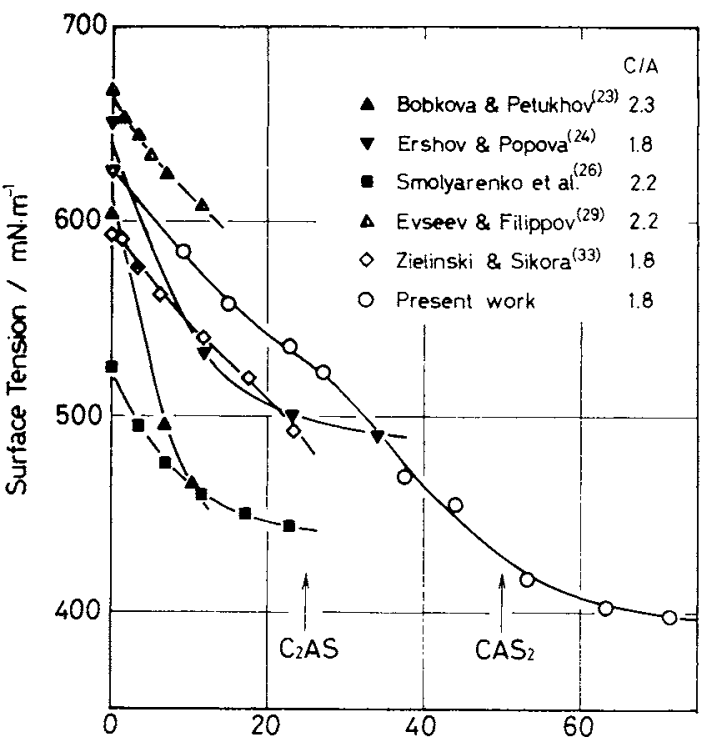

Concentration of $\mathrm{SiO}_{2} / \mathrm{mol} \%$

Fig.8 Surface tension of $\mathrm{CaO}-\mathrm{Al}_{2} \mathrm{O}_{3}-\mathrm{SiO}_{2}$ slag at constant $\mathrm{CaO}$ (mol\%) $/ \mathrm{Al}_{2} \mathrm{O}_{3}(\mathrm{~mol} \%)$. $\mathrm{C}: \mathrm{CaO}, \mathrm{A}: \mathrm{Al}_{2} \mathrm{O}_{3}, \mathrm{~S}: \mathrm{SiO}_{2}$

\section{5. $\mathrm{CaO}-\mathrm{Al}_{2} \mathrm{O}_{3}-\mathrm{SiO}_{2}$ 系}

組成との関係: Fig. 10 に, $\mathrm{CaO}-\mathrm{Al}_{2} \mathrm{O}_{3}-\mathrm{SiO}_{2}$ 系大ラグの 表面張力の $1873 \mathrm{~K}$ での測足值をもとに描いた等表面張力 線を示す．表面張力は全測定組成箸囲で, $\mathrm{SiO}_{2}$ 濃度の增加 とともに低下する。. $\mathrm{SiO}_{2}$ 濃度一定では, 大部分の組成範 困で，郡司ら ${ }^{(2)}$ の結果と同様，表面張力は $\mathrm{Al}_{2} \mathrm{O}_{3}$ 濃度とと もに減少古るが, $\mathrm{SiO}_{2} 58 \sim 62 \mathrm{~mol} \%, \mathrm{Al}_{2} \mathrm{O}_{3}$ 約 $5 \mathrm{~mol} \%$ 以 


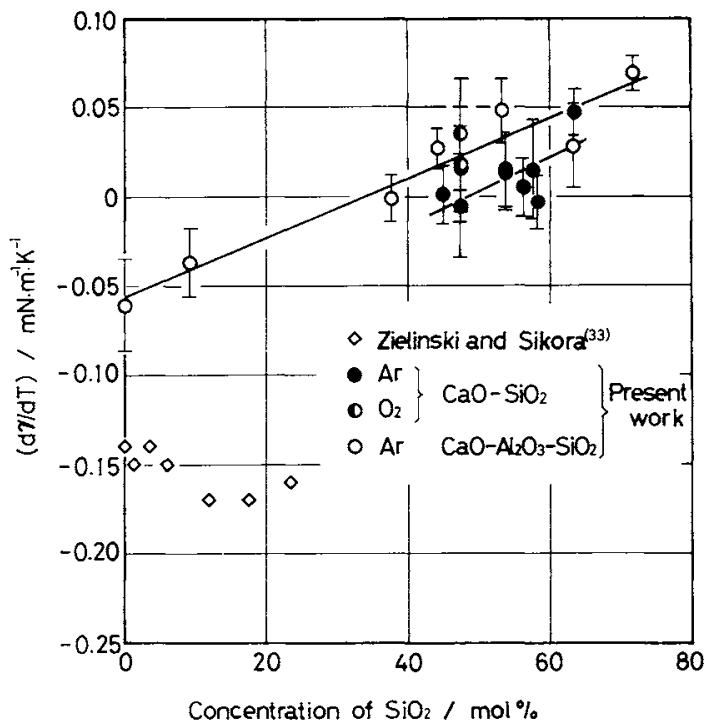

Fig.9 Temperature coefficient of surface tension of $\mathrm{CaO}-\mathrm{Al}_{2} \mathrm{O}_{3}-\mathrm{SiO}_{2}$ slag at $\mathrm{CaO}(\mathrm{mol} \%) / \mathrm{Al}_{2} \mathrm{O}_{3}(\mathrm{~mol} \%)$ $=1.8$.



Fig.10 Lines of constant surface tension (in $\mathrm{mN} / \mathrm{m}$ ) of $\mathrm{CaO}-\mathrm{Al}_{2} \mathrm{O}_{3}-\mathrm{SiO}_{2}$ slag at $1873 \mathrm{~K}$.

下では,郡司ら ${ }^{(2)} の$ 結果と異なり, $\mathrm{Al}_{2} \mathrm{O}_{3}$ 濃度の増加ととも に表面張力は增加する。表面张力は郡司ら ${ }^{(2)}$ の值と比較し $\tau, \mathrm{CaO}-\mathrm{SiO}_{2}$ 系の場合と同様, 全般に大をく，最大 40 $\mathrm{mN} / \mathrm{m}$ 程度の差がある. $\mathrm{SiO}_{2} 30 \mathrm{~mol} \%$ 以上での $\mathrm{CaO}-$ $\mathrm{Al}_{2} \mathrm{O}_{3}-\mathrm{SiO}_{2}$ 系の测定結果は, 郡司 $5^{(2)}$ 以外比もいくつか

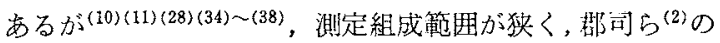
指摘のよらにばらつきも大きく，組成との明膫な関係は見 出しにくい.

温度との関係：Fig.11 亿表面泼力の温度係数 $\mathrm{d} \gamma / \mathrm{d} T$ の 測定值と，それをるとに描いた等 $\mathrm{d} r / \mathrm{d} T$ 線を実線で示す。 図に示寸 $\mathrm{d} r / \mathrm{d} T$ の值は，すべて表面張力の測定が 3 点以 上の温度でなされたスラグに対してのみ求めたものであ る. $\mathrm{CaO}-\mathrm{SiO}_{2}$ 系扎よび, $\mathrm{CaO}(\mathrm{mol} \%) / \mathrm{Al}_{2} \mathrm{O}_{3}(\mathrm{~mol} \%)$ 一定



Fig.11 Temperature coefficient of surface tension (in $\mathrm{mN} / \mathrm{m} \cdot \mathrm{K}$ ) of $\mathrm{CaO}-\mathrm{Al}_{2} \mathrm{O}_{3}-\mathrm{SiO}_{2}$ slag.

での $\mathrm{SiO}_{2}$ 濃度との関係と同样, $\mathrm{SiO}_{2}$ 濃度の增加とともに $\mathrm{d} r / \mathrm{d} T$ は負から正人と增加する. $\mathrm{SiO}_{2}$ 濃度一定の場合, $\mathrm{SiO}_{2}$ 濃度が約 $60 \mathrm{~mol} \%$ 以下では， $\mathrm{Al}_{2} \mathrm{O}_{3}$ 濃度の增加とと

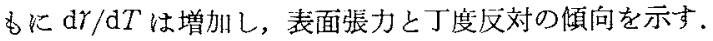
$\mathrm{d} r / \mathrm{d} T$ に関するこれまでの他の測定結果(11)(28)(33) -(35)(37) ${ }^{(38)}$ は測定点が少く，しか子间一組成笧囲でも測定者によ って正負反対の值を示すこともあり，組成との関係は明ら かでなかったわすずかに Barrett ら ${ }^{(35)}$ の結果が比較的測定 点も多く, $\mathrm{SiO}_{2}$ 濃度の增加とともに $\mathrm{d} \gamma / \mathrm{d} T$ 加增加する傾 向がみられる程度である。本測定結果に比して，他の測定 者の $\mathrm{d} \gamma / \mathrm{d} T$ はその絶対值がかなり大きい.

本測定で得られたよらな $\mathrm{SiO}_{2}$ 䟴度の高い組成範西にお いて，表面張力の温度俰数が正になる現象は King ${ }^{(10)}$ によ り見出されて以来，かなりの睻定結果が報告されている。 本測定結果では，乙かも $\mathrm{Al}_{2} \mathrm{O}_{3}$ の添加が $\mathrm{d} \gamma / \mathrm{d} T$ の増加を いっそ弓时長し， $\mathrm{Al}_{2} \mathrm{O}_{3}$ を含をない場合に比べてより低い $\mathrm{SiO}_{2}$ 濃度でも $\mathrm{d} \gamma / \mathrm{d} T$ が正の值を示している。この組成範 囲での $\mathrm{Al}_{2} \mathrm{O}_{3}$ は Kozakevitch(39)の秥度の測定結果に执い ても， $\mathrm{SiO}_{2}$ の作用をより期長し， $\mathrm{Al}_{2} \mathrm{O}_{3}$ は酸性の作用を示 している。本測定で得られた $\mathrm{d} \gamma / \mathrm{d} T$ に対する $\mathrm{Al}_{2} \mathrm{O}_{3}$ の作 用は，この粘度に対する作用とよく一致する。 $\mathrm{d} r / \mathrm{d} T$ が正 になる理山としては，大きな理酸陰イオンが温度の上昇と ともに切断される可能性 ${ }^{(10)}$ ，あるいは表面活性成分の脱 着 ${ }^{(40)}$ によるとの考えがある。しかし King(10)は, 後者の脱 着の可能性については, $\mathrm{SiO}_{2}$ が谢い表面活性作用しかな いことから否定的である。本溳定組成範国では，上钝粘度

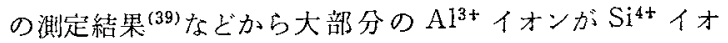
ンと同様の酸素 4 配位をして，大きなアルミノ珪酸陰イオ 
ンを形成するものと一般に考克られている。これらの考光 に従光ば， $\mathrm{d} r / \mathrm{d} T$ への $\mathrm{Al}_{2} \mathrm{O}_{3}$ の作用はこの大きなアルミ ，珄酸陰イオンが，珪酸陰イオンの場合と同椂に温度の上 昇ととるに切断されるとして理解するのが妥当であるう。

\section{IV. 結 言}

スラグ皆滴の大きさを自由に調節できる装置を用いて， 毇滴法によって CaO $-\mathrm{SiO}_{2}, \mathrm{CaO}-\mathrm{Al}_{2} \mathrm{O}_{3}, \mathrm{CaO}-\mathrm{Al}_{2} \mathrm{O}_{3}-\mathrm{SiO}_{2}$ 系溶骶スラグの表面張力を，液相線温度直上付近から 1873 $\mathrm{K}$ までの間で測定し，次の結果を得た。

（1）最大泡生法と異なり，本測定装置によれば静滴法と 同様の静的な状態で溶融スラグの表面张才の湘定ができ る，乙の場合の測定值の再現性は，約士1.3\%であった。

（2）䀣滴を急激に縮小，次いで堌大させた時に，式(1) より算出されるとの僆は，縮小時には減少し增大時には缩 小増大以前のるとの值に回復する傾向が浔められた。

（3）表面張力の温度ヒステリシスは，本測定精度内では 見出されなかった。

(4) $\mathrm{CaO}-\mathrm{SiO}_{2}$ 系スラグの表面㲀力は，最近の他の測定 者の値と比較的よく一致したが，表面張力-\% $\% \mathrm{SiO}_{2}$ 曲線に Wollastonite 組成付近で凸部の存在することが認められ た，表面張力の温度係数は King(10)の結果に近い。

(5) $\mathrm{CaO}-\mathrm{Al}_{2} \mathrm{O}_{3}$ 系スラグの表面張力は，同一の密度值を 用いた静滴法による局井ら ${ }^{(9)}$ の値とょく一致した，

(6) $\mathrm{CaO}\left(\mathrm{mol}_{\%} \% / \mathrm{Al}_{2} \mathrm{O}_{3}(\mathrm{~mol} \%)=1.8\right.$ のスラグでは, 表 面張力は $\mathrm{SiO}_{2}$ 濃度の增加とともに減少し, Gehlenite 組 成付近で $\mathrm{CaO}-\mathrm{SiO}_{2}$ 系之同様, 凸部の出現の可能性が認め られた。 $\mathrm{d} r / \mathrm{d} T$ は $\mathrm{SiO}_{2}$ 濃度の增加とともに增加し, $\mathrm{CaO}$ $\mathrm{SiO}_{2}$ 系より低い $\mathrm{SiO}_{2}$ 濃度で負から正へと移行した。

(7) $\mathrm{CaO}-\mathrm{Al}_{2} \mathrm{O}_{3}-\mathrm{SiO}_{2}$ 系スラグに蛙ける等表面張力線 $(1873 \mathrm{~K})$ ，等 $\mathrm{d} r / \mathrm{d} T$ 線を得た，表面張力は全測定組成範 囲において $\mathrm{SiO}_{2}$ 濃度の增加とともに低下し， $\mathrm{SiO}_{2}$ 濃度一 定のるとでは，高 $\mathrm{SiO}_{2}$ 低 $\mathrm{Al}_{2} \mathrm{O}_{3}$ の一部の組成を除いて $\mathrm{Al}_{2} \mathrm{O}_{3}$ 濃度の增加とともに低下した。 $\mathrm{d} r / \mathrm{d} T$ はこれとは区 対飞, $\mathrm{SiO}_{2}$ 濃度の増加ととるに大をくなり， $\mathrm{SiO}_{2}$ 濃度一 定のむとでは, $\mathrm{SiO}_{2} 60 \mathrm{~mol} \%$ 以下で $\mathrm{Al}_{2} \mathrm{O}_{3}$ 濃度の堌加と ともに大きくなる傾向を示した。

終りに，本実験に協力された佳々木豊重，西惫治， 松谷俊彦，久野井詩，原野宏の諸君に深く感謝する。

\section{文载}

（1）鉄鋼基礎共同研究会溶鋼溶涬部会：溶鉄・溶㳯の物 性値便覧，特別報告畫No.12，日本鉄鍋協会， (1972), 130.

(2) K.Gunji and T.Dan : Transactions ISIJ, 14 (1974), 162.

（3）向牛楠宏，古河洋交，土川孝：鉄之鋼，63(1977)， 1484 .

(4) S.Fordham : Proc.Roy.Soc., 194A (1948), 1.

（5）向井楠宏, 加藤時夫, 圾尾 弘: 鉄と銅, 59(1973), 55 .

(6) Y. E. Lee and D. R. Gaskell : Met.Trans., 5 (1974), 853.
(7) J. O'M. Bockris, J. W. Tomlinson and J. L. White : Trans.Farad.Soc., 52(1956), 299.

(8) R.Kammel and H.Winterhager : Erzmetall, 18 (1965), 9.

（9）向井楠宏，坂尾 弘：豊田研究報告，21 (1968), 18 .

(10) T. B. King : J.Soc. Glass. Technol., 35(1951), 241.

(11) S.I.Popel and O.A.Esin : Zhur.Neorg.Khim., $2(1957), 632$.

(12) C.F.Cooper and J.A.Kitchener: J.Iron Steel Inst., 193(1959) , 48.

(13) T.B.King : Trans.Met.Soc.AIME, 230(1964), 1671, (1961, M.I.T., Cambridge Mass.)

(14) J.H. Swisher and C.I.McCabe : Trans.Met. Soc. AIME, 230(1964), 1669.

(15) A.S.Panov, I.S.Kulikov and L.M.Tsylev : Surface Phenomena in Metallurgical Processes, Consultants Bureau Enterprises, Inc., (1965), 146.

（16）小野清雄，郡司好喜，荒木 透：日本金属学会誌， $33(1969), 299$.

(17) S.K.Sharma and W.O.Philbrook : Script.Met.s $4(1970), 107$.

(18) S. K. Sharma and W. O. Philbrook : Proc. ICSTIS, Supp1.Trans.ISIJ, $11(1971), 569$.

(19) Y.Kojima : Trans.ISIJ, 11(1971), 349.

(20) J.O'M.Bockris and D.C.Lowe : Proc.Roy.Soc., $226(1954), 423$.

(21) J.O'M.Bockris, J.A.Kitchener, S.Ignatowicz and J.W.Tomlinson : Disc.Farad.Soc.,4 (1948), 265.

(22) J.W.Tomlinson, M.S.R.Heynes and J.O'M. Bockris : Trans.Farady Soc., 54 (1958), 1822.

(23) O.S.Bobkova and V.S.Petukhov : Izdatelstvo Akad. Nauk USSR, Kiev, (1963), 212.

(24) G. S. Ershov and E. A. Popova : Zh. Neorg. Khim., 9(1964), 654 .

(25) A. A. Deryabin and S. I. Popel : Izv. VUZov. Chern.Met.,(1964)8, 5 .

(26) V.D.Smolyarenko, A.M.Yakushev and F.P. Edneral : Izv. VUZov.Chern.Met., (1965) 1, 55.

(27) S.B. Yakobashivili, T.G.Mudzhiri and A.V. Sklyarov : Avtomaticheskaya Svarka, (1965) 8,44 .


$52(1966), 1427$.

(29) P.P.Evseev and A.F.Filippov : IzV. VUZov. Chern. Met., (1967) 3, 55 .

(30) V.P.Elyutin, B.S.Mitin and Yu.S.Anisimov: Izv. VUZov.Chern. Met., (1974) 4, 42.

(31) B.Sikora and M.Zielinski: Hutnik, 41 (1974), 433.

(32) A. S. Zubrev, V. V. Shakhnovich and M.F. Sidorenko : IzV. Akad. Nauk SSSR Metal., (1976) 2,22 .

(33) M. Zielinski and B. Sikora : P. Inst. Metal Zelaza, 29 (1977), 157.

(34) R.E.Boni and G.Derge : J. Metals, 8(1956), 59 .

(35) L.R,Barrett and A.G.Thomas : J.Soc., Glass Technol., 43(1959), 179.

(36) K. K. Strelov, D. I. Lopatinskaya and L.I. Sarapulova : Ogneupory, (1974) 10, 36.

(37) 高柳] 猛, 加藤 誠, 菩輪 晋：鋳物, 48(1976), 779 .

(38) A.Staronka and M.Piekarska : Arch.Hutn., 23 (1978), 119.

(39) P.Kozakevitch : Rev.Met., 57 (1960), 149.

(40) F.D.Richardson : Physical Chemistry of Melts in Metallurgy, Vol.2, Academic Press.,(1974), 441. 